\title{
Heavy Metals Assessment In Water, Sediments And Selected Aquatic Organisms In Lake Asejire, Nigeria
}

\author{
Jenyo-Oni A. \\ Department of Aquaculture and Fisheries Management, \\ University of Ibadan, Ibadan, Nigeria \\ Oladele A. $\mathrm{H}$. \\ Department of Fisheries and Aquacultural Technology, \\ Federal University Dutsin-Ma, Dutsin-Ma, Nigeria
}

doi: 10.19044/esj.2016.v12n24p339 URL:http://dx.doi.org/10.19044/esj.2016.v12n24p339

\begin{abstract}
Rapid urbanization and industrialization in developing countries have been associated with production and deposition of hazardous wastes in aquatic environments. Heavy metals are major components of these wastes which have been implicated in several metal-related diseases and food poisoning in man. This study evaluated iron, lead, cobalt, nickel, chromium and cadmium concentrations in water, sediment, Nile Tilapia (Oreochromis niloticus) and African river prawn (Macrobrachium vollenhovenii) samples of Lake Asejire, Oyo State, Nigeria. The concentration of these metals was determined spectrophotometrically in three locations along the course of the lake. Results revealed that only iron and lead were detected in water samples. However, all the metals were found in sediments, Nile Tilapia and African river prawn. Iron had the highest mean concentrations (mg kg ${ }^{-1}$ ) of $2.392 \pm 0.015,7.4314 \pm 1.184$, and $1.6100 \pm 0.099$ in sediments, fish and prawn respectively. Significant differences was found across each sample type for the metals determined. The detection of these metals in Lake Asejire call for close environmental monitoring and adequate public awareness. This is necessary to discourage further pollution which could lead to high metal concentration and metal poisoning.
\end{abstract}

Keywords: Heavy metals, Nile Tilapia, African river prawn, Lake Asejire

\section{Introduction}

Pollution brings undesirable changes in the environment, which could affect the compositions of an ecosystem. Aquatic ecosystems are affected by several health stressors that significantly deplete biodiversity. The loss of biodiversity and its effects are predicted to be greater for aquatic ecosystems 
than for terrestrial ecosystems in future (Sala et al., 2000). The increase in pollution of aquatic environments could be attributed to increasing agricultural practices, industrial development, urbanization and inadequate consideration for environmental impact, among other factors. The indiscriminate release of liquid wastes of organic and inorganic nature which changes physico-chemical characteristics of water and causes hazard to flora and fauna of the aquatic ecosystem and man (Ghorade et al., 2015). Contaminants usually remain either in soluble or suspension form and finally tend to settle down to the bottom or are taken up by immensely by benthic organisms in aquatic systems. Inland waters manifest more pronounced effects of indiscriminate waste deposition due to thier small sizes, unlike the seas and oceans. Hence, the impact of waste deposition is felt more by aquatic biota in wetland, lakes, streams and rivers.

Heavy metals are the most important forms of aquatic pollutants and may accumulate in the tissues of fish, which are often at the top of the aquatic food chain (Dirican et al., 2013). The progressive and irreversible accumulation of metals in various organs of aquatic creatures ultimately leads to metal-related diseases in the long run because of the toxicity of the metals, thereby endangering the aquatic biota and other organisms (Mallampati et al., 2007). Among the aquatic organisms, fishes remain the important member which often accumulates metals in different body parts. The danger of heavy metal pollutants in water bodies lies in two aspects with respect to their impact. Firstly, heavy metals have the ability to persist in natural ecosystems for an extended period. Secondly, they have the ability to accumulate in successive levels of the biological chain, thereby causing acute and chronic diseases (Akpor and Muchie, 2010). Their toxicity has been demonstrated long ago; Greek and Roman physicians diagnosed symptoms of acute lead poisoning long before toxicology became a science (Ayodele et al., 1991). Exposure to heavy metals has been linked to developmental retardation, various cancers, kidney damage and even death (Abdulaziz and Mohammed, 1997).

Aquatic toxicity testing in water pollution control is paramount to determining the concentration of toxicants and their impacts on aquatic animals. Many studies have been conducted to measure the concentration levels of pollutants in aquatic ecosystems. Omitoyin et al. (2003) measured copper, lead and zinc concentrations in samples of Clarias gariepinus from Eleyele Lake, Ibadan, Nigeria; Omitoyin and Ajani (2007) investigated the accumulation levels of these metals (copper, lead and zinc) in water samples in addition with studying the feeding habits of fish species in the lake while Ayeloja et al. (2014) studied copper, lead, cadmium, zinc, chromium and manganese concentrations in water and samples of Clarias gariepinus, Hepsetus odoe and Oreochromis niloticus in Eleyele lake. However, scanty 
information is available on the metal content of water, sediment and aquatic organisms in Lake Asejire.

Lake Asejire, a non-natural lake constructed on River Oshun, located in Egbeda Local Government Area of Oyo State, Southwestern Nigeria, is one of the numerous lakes in Nigeria facing pollution problems. Reports of domestic discharge of household wastes, effluent release and drainage of agrochemicals from surrounding farmland has raised concern on the heavy metal content of the lake. Nile Tilapia (Oreochromis niloticus) and African river prawn (Macrobrachium vollenhovenii) are notable fin and shell fish species inhabiting Lake Asejire. They have immense nutritional and economic importance, in addition to being dominant edible aquatic organisms resident in the reservoir. Not only are they available as pollution bio-indicators, their sensitivity to heavy-metal contamination and accumulation (Agbozu et al., 2007) is another basis for their selection for this study. Therefore, this study examined the concentrations of iron (Fe), lead $(\mathrm{Pb})$, cobalt $(\mathrm{Co})$, nickel $(\mathrm{Ni})$, chromium $(\mathrm{Cr})$ and cadmium (Cd) in water, sediment, Oreochromis niloticus and Macrobrachium vollenhovenii samples in Lake Asejire.

\section{Materials and Methods \\ Study Area}

The study was carried out on Lake Asejire, a man-made lake constructed on River Oshun, in Egbeda Local Government Area of Oyo State, Southwest Nigeria. River Oshun is one of the West African rivers which do not drain into River Niger but discharges into coastal lagoons and creeks bordering the Atlantic Ocean. The lake lies on $04^{\circ} 07^{\prime}$ East and $07^{\circ} 21^{\prime}$ North at an altitude of 137 metres above sea level, covering a length of $19.5 \mathrm{~km}$ (Ayoade et al., 2007). The lake, located about $33.8 \mathrm{~km}$ from Ibadan, has numerous other inflows joining the lake at different points (Egborge, 1977). Ogunleye (1982) reported that River Oshun was dammed at Asejire for the purpose of providing potable water to Ibadan metropolis and its surrounding communities. The lake has an approximate gross storage of 7,403 million litres. The construction of the lake divides the fishing area into two main zones, namely the upstream and the downstream. Despite identifying twenty-seven species which belong to thirteen families, Lake Asejire could be best described as Tilapia and Chrysichthys fisheries owing to their dominant population (Ipinmoroti, (2013).

\section{Collection of samples}

Three (3) sampling locations were chosen along the course of the water body based on the criteria of proximity to point of damming the river. A sampling location was located upstream, midstream and downstream 
where collection of water, sediment, fish and prawn samples was done. Sampling was carried out monthly for a total duration of six months between January and June, 2015. The study period comprises of 3 months of dry season (January - March) and wet season (April - June). Samples were obtained between 7.00 and 10.00 hours during the designated days. Physicochemical water parameters, such as temperature, dissolved oxygen (DO), $\mathrm{pH}$, conductivity, alkalinity, total hardness and total dissolved solid (TDS), were measured in addition to determining the concentration of heavy metals in water, sediment, fish and prawn samples obtained from each sampling location. Surface water temperature was measured with mercury bulb field thermometer at the point of sample collection. Water samples were collected from each sampling location in 2-litre plastic sampling bottles using standard methods (APHA, 1992) and analysed for the metal content.

Sediment samples were collected from each of the three sampling locations with a Van veen grab $\left(0.1 \mathrm{~m}^{2}\right)$. Composite sediment samples were obtained from each location and transported in labelled polyethylene bags, previously cleaned and treated with 5\% nitric acid and rinsed with distilled water (Achionye-Nzeh and Isimaikaiye, 2010). The polythene bags were rinsed with water samples at the point of sediment collection before the sediment samples were put into it. Samples of Nile Tilapia (Oreochromis niloticus) and African river prawn (Macrobrachium vollenhovenii) were collected with the services of local fishermen licensed to explore the fisheries of the lake, using cast and gill nets. Weight ranges of 100-150 g and 50-75 g for Tilapia and prawn, respectively, were sampled and analysed for heavy metal determination.

\section{Laboratory Analysis}

The $\mathrm{pH}$, conductivity, total dissolved solids (TDS) of the water were measured using probe meter (Hana portable $\mathrm{pH} / \mathrm{EC} / \mathrm{TDS} /$ temperature meter, HI 98129 model), dissolved oxygen (DO) was measured using Winkler's method, alkalinity was measured using titrimetric method, and total hardness was measured using spectrophotometer. Buck Scientific Atomic Absorption Spectrophotometer (VGP 210/211 model) was used to determine concentrations of $\mathrm{Fe}, \mathrm{Pb}, \mathrm{Co}, \mathrm{Ni}, \mathrm{Cr}$ and $\mathrm{Cd}$ in the water samples, as described by Peer and Rosen (1977).

Sediment samples were air-dried and sieved with $0.5 \mathrm{~mm}$ sieve in preparation for digestion and heavy metal analysis. Metal content of the digested sediment samples was determined using Atomic Absorption Spectrophotometer (Buck scientific 210/211 VGP model). Samples of fish and prawn collected were cleaned with tap water, weighed and oven-dried at $105^{\circ} \mathrm{C}$ till a constant weight was obtained. 
Standard length of fish samples was measured using a measuring board while the standard length of prawn samples was determined using an inelastic rubber thread. To measure the standard length of the prawn, the thread was spread firmly to cover the full length of the prawn samples. The length of the rubber thread which spans the entire prawn length was measured on a metre rule. An OHAUS model of weighing balance was used for determining both fresh and dried weights prior to oven drying. Dried samples were ground into powdery form, digested and tested for heavy metal contents using Atomic Absorption Spectrophotometer (Buck scientific 210/211 VGP model). The concentration (mg $\mathrm{kg}^{1}{ }^{1}$ ) of the metals was calculated, with reference to Peer and Rosen (1977).

\section{Statistical analysis}

The data obtained were subjected to descriptive and inferential statistics. Descriptive statistics, mainly mean and standard deviation, was used to describe each of the water quality parameters as well as concentrations of metals in the water, sediment, fish and prawn samples. Analysis of Variance (ANOVA) was used to test for significant differences in heavy metal content of the 4 sample types (water, sediment, fish and prawn. One-way ANOVA was used in all cases for mean metal level comparisons at 5\% level of significance.

\section{Results}

The physico-chemical parameters of water as well as heavy metal concentrations in water, sediment, fish and prawn samples from Lake Asejire are presented in Tables 1 and 2. Each of the physico-chemical parameters of water measured varied throughout the period of this study (Table 1).

Table 1: Physico-chemical parameters of water in Lake Asejire

\begin{tabular}{cc}
\hline Parameters & Mean \pm Std Dev. \\
\hline Temperature $\left({ }^{\circ} \mathrm{C}\right)$ & $28.47 \pm 0.49$ \\
pH & $7.49 \pm 0.30$ \\
Dissolved Oxygen $\left(\mathrm{mg} \mathrm{l}^{-1}\right)$ & $5.72 \pm 1.18$ \\
Conductivity $\left(\mu \mathrm{cm}^{-1}\right)$ & $8.33 \pm 0.62$ \\
Total Alkalinity $\left(\mathrm{mg} \mathrm{l}^{-1}\right)$ & $1.44 \pm 0.13$ \\
Total hardness $\left(\mathrm{mg} \mathrm{l}^{-1}\right)$ & $2.44 \pm 0.73$ \\
Total Dissolved Solids $\left(\mathrm{mg} \mathrm{l}^{-1}\right)$ & $0.13 \pm 0.02$ \\
\hline
\end{tabular}

Table 2: Mean concentrations of heavy metal in water, sediment, fish and prawn samples of Lake Asejire

\begin{tabular}{|c|c|c|c|c|c|c|}
\hline Sample type & Iron & Lead & Cobalt & Nickel & Chromium & Cadmium \\
\hline $\begin{array}{c}\text { Water }\left(m g \mathrm{l}^{-}\right. \\
1\end{array}$ & $\begin{array}{c}0.0066 \pm 0 . \\
000^{\mathrm{a}}\end{array}$ & $\begin{array}{c}0.0150 \pm 0 . \\
028^{\mathrm{a}}\end{array}$ & $\mathrm{Nd}$ & $\mathrm{Nd}$ & $\mathrm{Nd}$ & $\mathrm{Nd}$ \\
\hline $\begin{array}{c}\text { Sediment } \\
\left(\mathrm{mg} \mathrm{kg}^{-1}\right)\end{array}$ & $\begin{array}{c}2.392 \pm 0.0 \\
15^{\mathrm{b}}\end{array}$ & $\begin{array}{c}0.0740 \pm 0 . \\
018^{\mathrm{b}}\end{array}$ & $\begin{array}{c}0.0266 \pm 0 . \\
011^{\mathrm{b}}\end{array}$ & $\begin{array}{c}0.0174 \pm 0 . \\
011^{\mathrm{a}}\end{array}$ & $\begin{array}{c}0.0154 \pm 0.0 \\
04^{\mathrm{b}}\end{array}$ & $\begin{array}{c}0.0834 \pm 0 . \\
037^{\mathrm{b}}\end{array}$ \\
\hline
\end{tabular}




\begin{tabular}{|c|c|c|c|c|c|c|}
\hline Fish (mg kg & $7.4314 \pm 1$. & $0.0532 \pm 0$. & $0.0056 \pm 0$. & $0.0156 \pm 0$. & $0.0038 \pm 0.0$ & $0.0640 \pm 0$. \\
1 ) & $184^{\mathrm{c}}$ & $008^{\mathrm{b}}$ & $008^{\mathrm{a}}$ & $009^{\mathrm{a}}$ & $07^{\mathrm{a}}$ & $018^{\mathrm{b}}$ \\
\hline Prawn (mg & $1.6100 \pm 0$. & $0.1036 \pm 0$. & $0.0054 \pm 0$. & $0.0188 \pm 0$. & $0.00098 \pm 0$. & $0.0446 \pm 0$. \\
$\left.\mathrm{kg}^{-1}\right)$ & $099^{\mathrm{b}}$ & $014^{\mathrm{c}}$ & $005^{\mathrm{a}}$ & $009^{\mathrm{a}}$ & $0009^{\mathrm{a}}$ & $012^{\mathrm{a}}$ \\
\hline
\end{tabular}

$\mathrm{Nd}=$ Not detectable

Means followed by the same superscript in each column are not significantly different $(\mathrm{p}<0.05)$

As evident in Table 2, most of the metals in the water samples had concentrations in non-detectable amounts, unlike concentrations observed in sediment, fish and prawn samples, which had varying degrees of metal accumulation. Also, iron and lead concentrations detected in the water samples were the lowest concentrations when compared with other sample types. In sediments, the metals were found in quantities less than $1 \mathrm{mg} \mathrm{kg}^{-1}$, except iron which showed a notably high concentration $(2.392 \pm 0.015 \mathrm{mg} \mathrm{kg}$ ${ }^{1}$ ). The order of occurrence of the metals in the sediment samples in descending trend was as follows: $\mathrm{Fe}>\mathrm{Cd}>\mathrm{Pb}>\mathrm{Co}>\mathrm{Ni}>\mathrm{Cr}$. In the fish and prawn samples, all the metals were found in relatively low quantities, except iron, which showed comparatively high concentration of $7.4314 \pm 1.184 \mathrm{mg} \mathrm{kg}^{-1}$ and $1.610 \pm 0.099 \mathrm{mg} \mathrm{kg}^{-1}$, respectively. However, the order of metal occurrence of the two aquatic organisms was different. While Nile Tilapia (O. niloticus) had the order $\mathrm{Fe}>\mathrm{Cd}>\mathrm{Pb}>\mathrm{Ni}>\mathrm{Co}>\mathrm{Cr}$; African river prawn (M. vollenhovenii) showed the following order: $\mathrm{Fe}>\mathrm{Pb}$ $>\mathrm{Cd}>\mathrm{Ni}>\mathrm{Co}>\mathrm{Cr}$. Unlike the accumulation pattern in the fish samples where cadmium concentration was higher than lead, the concentration of lead in the prawn samples was higher than cadmium, being the second highest metal concentration to iron. A bar chart representation of the distribution of the metals in each of the samples types is shown in Figure 1.

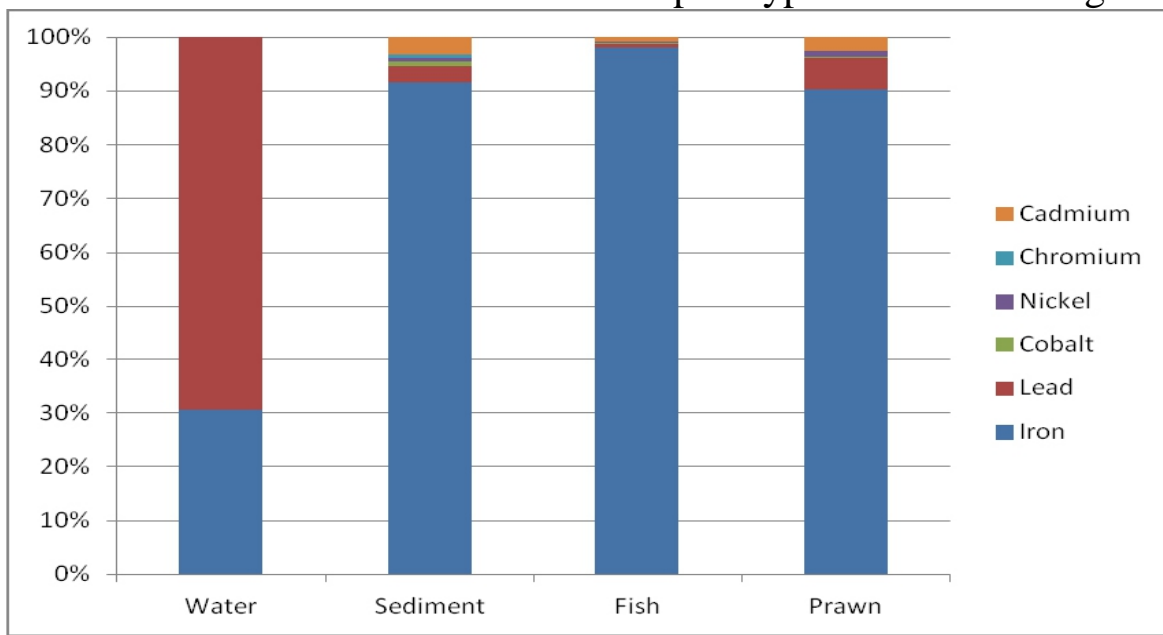

Figure 1: Distribution of metals in water, sediment, fish and prawn samples 
The iron content in the sample types showed significant differences $(p<0.05)$. The iron concentration in the water samples was significantly different $(\mathrm{p}<0.05)$ from concentrations in all other sample types; its concentrations in sediment and prawn samples were not significantly different. Similarly, lead concentration among the sample types was significantly different $(\mathrm{p}<0.05)$ except in sediment and fish samples, which showed no significant difference. Also, there was no significant difference between cobalt, nickel and chromium concentrations in fish and prawn samples. However, significant differences $(\mathrm{p}<0.05)$ were observed between cobalt concentrations in sediment and aquatic organisms, chromium concentrations in sediments and fish, as well as cadmium concentrations in sediment and prawn samples. Similarly, significant difference $(p<0.05)$ was displayed in cadmium concentrations observed in the fish and prawn samples.

\section{Discussion}

The physico-chemical parameters of the water samples from Lake Asejire were found within beneficial levels which support both human and aquatic animal usage. Dissolved oxygen concentration and the $\mathrm{pH}$ of water bodies are important parameters that determine the spatial and temporal distribution of aquatic organisms, particularly the fish fauna (Araoye, 2009). Dissolved oxygen is required for respiration by most aquatic animals. Apart from this, dissolved oxygen combines with other important elements such as carbon, sulphur, nitrogen and phosphorous to form carbonates, sulphates, nitrates and phosphates, respectively, which constitute the required compounds for the survival of aquatic organisms. In the absence of adequate oxygen levels, the above elements, among others, could form compounds which are toxic to the aquatic biota. The appropriateness of dissolved oxygen, $\mathrm{pH}$ and other water parameters could be the basis for the thriving fisheries in the lake, which is in agreement with findings of Ayoade et al. (2007).

As revealed in the results, it is evident that the concentration of the heavy metals in the water samples was relatively low. A number of the metals (cobalt, nickel, chromium and cadmium) were present in nondetectable quantities in water samples, contrary to their concentration levels in sediments, fish and prawn samples. This could be attributed to strong variations of flow rate, pollutant input and transport as well as sedimentation of the metals. This is in consonance with the findings of Haslam (1990). The presence of iron and lead could be attributed to the presence of abandoned parts of heavy pumping machines and equipment which littered the surroundings of the lake, mainly within the vicinity of the dam. The batteries of these machines contain some lead compounds that could find their way 
into the water body through erosion and/or drainage especially during rainfall. Erosion of corroded lead-containing materials may lead to increased lead concentrations in the water body. Also, some iron and lead compounds could have their sources in fertilizers, herbicides and pesticides used on crop farms within the lake vicinity. Water erosion and drainage could also transport compounds of these metals from domestic wastes from near and far households. This is in line with the field reports and information obtained from some fishermen who confirmed that debris and wastes from domestic activities are usually found floating on the water.

The physico-chemical parameters and metal concentration in water samples of Lake Asejire when compared with National standards (National Agency for Food and Drug Administration and Control (NAFDAC) and Standard Organization of Nigeria, (SON)) and International standard (World Health Organization, WHO) revealed that all the parameters were within the threshold levels (Table 3). This comparison becomes necessary to reveal the status of the lake as it concerns the safe use of the water body for domestic purpose and as a healthy aquatic habitat. As evident on Table 3, all the parameters had concentrations below the limits of NAFDAC, SON and WHO except iron. This points to the fact that concentration of pollutants in the water column is relatively low, which may be attributed to continuous flow of the lake notably through the Asejire dam gate. The higher the flow rate, the lower will be the resident time spent by the pollutants in the water body. High concentration of iron in the water column may be due to iron abundance in the underlying soil of the lake (Kendrick et al., 1992), in addition to erosion of metallic parts of abandoned machines and equipments littering the lake vicinity.

Table 3: Comparison of physico-chemical parameters and mean metal concentration in water samples with NAFDAC, SON (2007) and WHO (2006) standards

\begin{tabular}{|c|c|c|c|c|c|c|}
\hline \multirow[b]{2}{*}{$\mathrm{S} / \mathrm{N}$} & \multirow[b]{2}{*}{ Parameter } & \multirow[b]{2}{*}{$\begin{array}{l}\text { This } \\
\text { study }\end{array}$} & \multirow{2}{*}{$\begin{array}{c}\text { NAFDAC } \\
\text { Maximum } \\
\text { allowed limits }\end{array}$} & \multirow[b]{2}{*}{$\begin{array}{c}\text { SON } \\
\text { standard }\end{array}$} & \multicolumn{2}{|c|}{ WHO standard } \\
\hline & & & & & $\begin{array}{l}\text { Highest } \\
\text { desirable }\end{array}$ & $\begin{array}{l}\text { Maximum } \\
\text { permissible }\end{array}$ \\
\hline 1 & Temperature $\left({ }^{\circ} \mathrm{C}\right)$ & 28.5 & - & - & $30-32$ & $30-32$ \\
\hline 2 & $\mathrm{pH}$ & 7.492 & $6.5-8.5$ & $6.5-8.5$ & $7.0-8.9$ & $6.5-9.5$ \\
\hline 3 & $\begin{array}{c}\text { Dissolved Oxygen (mg } \\
\mathrm{l}^{-1} \text { ) }\end{array}$ & 5.720 & - & - & - & - \\
\hline 4 & Conductivity ( $\mu \mathrm{cm}^{-1}$ ) & 8.334 & 1000 & 1000 & 900 & 1200 \\
\hline 5 & Total Alkalinity (mg l' & 1.436 & 100 & 100 & 100 & 100 \\
\hline 6 & Total Hardness (mg l-1) & 2.442 & 100 & 100 & 100 & 100 \\
\hline 7 & Total Solids (mg l-1) & 0.126 & 500 & 500 & 500 & 1500 \\
\hline 8 & Iron $\left(\mathrm{mg} \mathrm{l}^{-1}\right)$ & 0.006 & 0.3 & 0.3 & 1 & 3 \\
\hline 9 & Lead (mg l-1) & $0.047 *$ & 0.01 & 0.01 & 0.01 & 0.01 \\
\hline 10 & Cobalt (mg l-1) & $\mathrm{Nd}$ & - & - & - & - \\
\hline 11 & Nickel (mg l-1) & $\mathrm{Nd}$ & - & - & - & 0.02 \\
\hline 12 & Chromium (mg l $\left.{ }^{-1}\right)$ & $\mathrm{Nd}$ & 0.05 & 0.05 & 0.05 & 0.05 \\
\hline 14 & Cadmium $\left(\mathrm{mg} \mathrm{l}^{-1}\right)$ & $\mathrm{Nd}$ & 0.003 & 0.003 & 0.003 & 0.003 \\
\hline
\end{tabular}

*Mean Concentration greater than the stipulated standards. 
In sediment samples, the mean metal concentration observed was relatively low, except for iron $\left(2.392 \pm 0.015 \mathrm{mg} \mathrm{kg}^{-1}\right)$ which was higher than $1 \mathrm{mg} \mathrm{kg}{ }^{-1}$; all other metals had mean concentrations below $1 \mathrm{mg} \mathrm{kg}^{-1}$. Responsible for the relatively high iron concentration may be a combination of factors, which include the fact that iron is the most abundant transition metal on earth (Kendrick et al., 1992). The high concentration recorded may also be attributed to human activities, such as the discharge of untreated sewage and use of metals and industrial materials that contain metals as well as the ability of the sediment to act as sink for metal and trace elements. It has also been reported that iron occurs at high concentration in most Nigeria soils, which are formed from basement rock minerals belonging to the major group of soils known as 'ferruginous' tropical soils, which are rich in iron oxides (Olowu et al., 2010). Adsorption and precipitation of trace metals by iron oxides may have been the basis for the low concentration of other metals, thus, helping in maintaining low trace metal level in the environment. Lead has been found to be considerably higher in clay fractions of soils (Adriano, 1986). The minute concentration of lead could, therefore, be traced largely to industrial sources, such as the automobile emissions, batteries of pumping equipment, metallic pipes and alloy products in the environment as well as drainage of lead compounds from adjacent crop farms treated with agro-chemicals. The role of lead-containing domestic wastes deposited into the lake from erosion, during rainy season, cannot be overlooked. Such eroded materials find thier way into the lake through inflows of feeding streams and rivers.

The presence of $\mathrm{Fe}, \mathrm{Pb}, \mathrm{Co}, \mathrm{Ni}, \mathrm{Cr}$ and $\mathrm{Cd}$ in sediments, fish and prawn samples indicated the exposure of the lake and its aquatic resources to pollution whose source(s) could be point and/or non-point sources. This is in agreement with the report of Ogbeibu and Ezeunara (2002) that rapid industrialization, coupled with technological advances in agriculture, has introduced various pollutants (synthetic and organic) into the aquatic ecosystems.

The observed variability in the concentration of heavy metals in the fish and prawn samples is a reflection of varying degrees of metal thresholds in the animals. This can be described as a function of fish and prawn homeostatic control mechanism as well as rate of bioaccumulation of metals, which is species-dependent. The absorptive differences that occurred between species in this investigation may be attributed to the differences in the absorptive capabilities among animals and the animals' anatomic considerations (Glenn et al., 2009). In constrast to other metals, the relatively high concentration of iron in the fish and prawn samples, may be attributed to the fact that iron is an essential micronutrient associated with many proteins and enzymes (Gil et al., 1997) in these aquatic animals. The 
relatively high concentration of iron in fish and prawn may also be ascribed to the abundance of the metal in inland waters where these animals live (Kendrick et al., 1992). The observed low concentrations of lead, cadmium and nickel in the fish and prawn samples may be attributed to their nondietary nature or due to efficient mechanism of elimination by these animals.

Cadmium had the second highest concentration in the fish samples and third behind iron and lead in the prawn samples. Major sources of cadmium include rock minerals from which the soil is formed, ores of zinc, copper and lead as well as from industrial wastes. Other sources of cadmium could include degenerated batteries, plastic products from household wastes as well as burning of tyres and rubber products. Cadmium has no known physiological role in aquatic organisms and is considered as one of the most toxic metals in the aquatic environment (Obasohan, 2008). The relatively low concentration of lead in the fish muscles is in consonance with the findings of Omitoyin and Ajani (2007), which indicates that the gills are the major area of bioaccumulation of lead. The mechanism of lead accumulation in the water column is likely to be through adsorption and complexing of free lead ions (Denny and Welsh, 1979). Also, cobalt, nickel and chromium were observed in relatively low concentrations in the fish and the prawn samples. This may have been accounted for by the fact that cobalt is a constituent of vitamin $B_{12}$ required by animals Oduwole (1997). Therefore, cobalt deficiency causes nutritional defects, while its presence in fish body at high concentration, beyond nutritional requirement, poses toxic concerns as means of poisoning. Similarly, fish accumulates nickel in different tissues when exposed mainly to elevated levels in their environment (Obasohan, 2008).

\section{Conclusion}

It is apparent from this study that Asejire Lake contains varying levels of $\mathrm{Fe}, \mathrm{Pb}, \mathrm{Co}, \mathrm{Ni}, \mathrm{Cr}$ and $\mathrm{Cd}$ as detected in the water, sediment, fish and prawn samples. The detection of these metals calls for close environmental monitoring. Although some of the sources of these metals could be natural, from rock minerals and/or ferruginous soil types common to tropical soils, it is of great importance to control the discharge of pollutants from point and non-point sources. Ensuring healthy status of the lake will improve the water quality, and preserve the biodiversity of the water body without posing any health risk to humans who consume aquatic products from the water body. There is need for public enlightenment on the importance of desisting from waste deposition in water bodies and erosion drainage ways. This will not only reduce incidence of water pollution but also allow for effective use of various water resources. 


\section{References:}

Abdulaziz, B.A. and Muhammad, H. (1997). Role of epidemiological studies in determining environmental impact on health in Saudi Arabia. - In: Book of Abstracts: Development and Environmental Impact Conference, Riyadh, Saudi Arabia. 196.

Adriano, D. C. (1986). Trace elements in the terrestrial environment, Donnelley and sons co, Vriginia, 533 pp.

Agbozu, I., Ekweozor, E. and Opuene, K. (2007). Survey of heavy metals in the catfish (Synodontis clarias). International Journals of Environmental Science and Technology 4: 93-97.

Achionye-Nzeh, C. G. and Isimaikaiye A. (2010). Fauna and flora composition and water quality of a reservoir in Ilorin, Nigeria. International Journal of Lakes and Rivers 3 (1): 7-15.

Akpor, O. B. and Muchie, M. (2010). Remediation of heavy metals in drinking water and wastewater treatment systems: Processes and applications. International Journal of Physical Sciences 5 (12): 1807-1817.

APHA (1992). Standard methods for the examination of water and wastewater, $18^{\text {th }}$ Edition. American Public Health Association, Washington DC, USA.

Araoye, P. A. (2009). The seasonal variation of $\mathrm{pH}$ and dissolved oxygen $\left(\mathrm{DO}_{2}\right)$ concentration in Asa lake Ilorin, Nigeria, International Journal of Physical Sciences 4(5): 271-274.

Ayeloja, A. A., George, F. O. A., Shorinmade, A. Y., Jimoh, W. A., Afolabi, Q. O. and Olawepo K. D. (2014). Heavy metal concentration in selected fish species from Eleyele reservoir Ibadan Oyo State South-western Nigeria. African Journal of Environmental Science and Technology 8 (7): 422 - 427. Ayoade, A., Fagade, S. and Adebisi, A. (2007). Diet and dietary habits of the fish Schilbe mystus (Siluriformes: Schilbeidae) in two artificial lakes in Southwestern Nigeria. Revista de Biologia Tropical (International Journal of Tropical Biology and Conservation) 56 (4): 1847-1848.

Ayodele, J. T., Momoh, R. U. and Aminu, M. (1991). Determination of heavy metals in Sharada industrial effluents. - In: Book of abstracts: Second National Environmental Seminar, FEPA, F.M.H., Natural Water Resources Institute, W.H.O., Kaduna State Water Board, 14 pp.

Denny, P. and Welsh, R. (1979). Lead accumulation in plankton blooms from Ulls water, the English Lake District. Journal of Environmental Pollution 18: 1-9.

Dirican, S., Çilek, S., Çiftçi, H., Bıyıkoğlu, M., Karaçınar, S. and Yokuş, A. (2013). Preliminary study on heavy metal concentrations of Anatolian Khramulya, Capoeta tinca (Heckel, 1843) from Çamligöze Dam Lake, Sivas, Turkey. Journal of Environmental Health Science and Engineering. 11 (7): 1-6. 
Egborge A. B. M. (1977). The hydrobiology and plankton of Lake Asejire, Ph.D. Thesis, University of Ibadan, Ibadan, Nigeria.

Ghorade, I. B., Jadhavar, V. R. and Patil, S. S. (2015). Assessment of Heavy Metal Content in Amba River water (Maharashtra). World Journal of Pharmacy and Pharmaceutical Sciences 4 (5): 1853-1860.

Gil, S. M., Gubala, M. A., Landers, C., Lasorsa, D. H., Crescelium, B. E. and Curtis, L. R. (1997). Heavy metals accumulation in sediment and fresh water fish in U.S Arctic Lakes. Environmental Toxicology and Chemistry 16: 733741.

Glenn, S. S., Kristine, J. M., Tessa, P. A., Elena, R., Josefina, D., Arnold, H. and Gliceria, R. (2009). Assessing heavy metals in the waters, fish and macroinvertebrates in Manila bay, Philippines. Journal of Applied Sciences in Environmental Sanitation 4 (3): 187-195.

Ipinmoroti M. O. (2013). Ichthyofauna diversity of Lake Asejire: Ecological implications. International Journal of Fisheries and Aquaculture 5 (10): 248-252.

Kendrick, M. J., May, J., Plishka, M. J. and Robinson, K. D. (1992). Metals in biological systems. Ellis Horwood Ltd, England.

Mallampati, S. R., Bhavesh, M., Sunil, D., Manish, J., Leena, K., Venkatrama, K. S. S., Shaik, B., Gadde, R. and Prashant, B. (2007). Bioaccumulation of heavy metals in some commercial fishes and crabs of the Gulf of Cambay, India. Current Science Journal 92 (11): 1489-1491.

Obasohan, E. E. (2008). Bioaccumulation of chromium, copper, maganese, nickel and lead in a freshwater cichlid, hemichromis fasciatus, from Ogba River in Benin City, Nigeria. African Journal of General Agriculture 4 (3): 141-152.

Oduwole, G. A. (1997). Indices of pollution in Ogunpa and Ona Rivers, Ibadan: Physico-chemical, trace and plankton studies, $\mathrm{PhD}$ Thesis, University of Ibadan, Ibadan, Nigeria.

Ogbeibu, A. E. and Ezeunara, P. U. (2002). Impact of brewery effluents on the Ikpoba River, using the fish communities as bio-indicators. Journal of Aquatic Resources 17: 35-44

Ogunleye, I. K. (1982). The structure and performance of fishermen at Asejire Dam, Oyo State. B.Sc. Thesis, University of Ibadan, Ibadan, Nigeria. Olowu, R. A., Ayejuyo, O. O., Adewuyi, G. O., Adejoro, I. A., Denloye, A. A. B., Babatunde, A. O. and Ogundajo, A. L. (2010). Determination of heavy metals in fish tissues, water and sediment from Epe and Badagry Lagoons, Lagos, Nigeria. E-Journal of Chemistry 7 (1): 215-221.

Omitoyin, B. O. and Ajani, E. K. (2007). Feeding habits and bioaccumulation of heavy metals in fishes of Eleyele Lake, Nigeria. Journal of Afrotropical Zoology (2007 Special issue), 165-169. 
Omitoyin, B. O., Ajani E. K. and Adebusoye, F. (2003). Bioaccumulation of copper, lead and zinc in the organs and tissues of Clarias gariepinus (Burchell 1822) in Eleyele Lake, Nigeria. Journal of Environmental Extension 4: 74-77.

Peer, J. R. and Rosen, W. G. (1977). Lead and cadmium content of urban garden vegetables. Trace Substances and Environmental Health 11: 399 405.

Sala, O. E., Chapin, F. S., Armesto, J. J., Berlow, E., Bloomfield, J., Dirzo, R., Huber-Sanwald, E., Huenneke, L. F., Jackson, R. B., Kinzig, A., Leemans, R., Lodge, D. M., Mooney, H. A., Oesterheld, M., Poff, N. L., Sykes, M. T., Walker, B. H., Walker, M. and Wall, D. H. (2000). Global biodiversity scenarios for the year 2100. Science 287: 1770-1774.

SON (2007). Standards for drinking water quality. Standard Organization of Nigeria, Abuja, Nigeria.

WHO (2006). Guidelines for drinking water quality. World Health Organization, Geneva, Netherlands 1: 491- 493. 